Article

\title{
Do Private Sustainability Standards Contribute to Income Growth and Poverty Alleviation? A Comparison of Different Coffee Certification Schemes in Ethiopia
}

\author{
Fikadu Mitiku ${ }^{1,2, *}$, Yann de Mey ${ }^{3}$, Jan Nyssen ${ }^{4}$ and Miet Maertens ${ }^{2}$ \\ 1 Department of Agricultural Economics and Extension, Jimma University College of Agriculture and \\ Veterinary Medicine, 307 Jimma, Ethiopia \\ 2 Division of Bioeconomics, Department of Earth and Environmental Sciences, KU Leuven, 3000 Leuven, \\ Belgium; Miet.Maertens@kuleuven.be \\ 3 Business Economics Group, Wageningen University \& Research, 6708 PB Wageningen, The Netherlands; \\ yann.demey@wur.nl \\ 4 Department of Geography, Ghent University, 9000 Gent, Belgium; Jan.Nyssen@UGent.be \\ * Correspondence: fikadumitiku.abdissa@kuleuven.be or fikadom@yahoo.com; \\ Tel.: +32-48-932-9621/+251-92-361-2548
}

Academic Editor: Moya Kneafsey

Received: 30 September 2016; Accepted: 6 February 2017; Published: 11 February 2017

\begin{abstract}
Private sustainability standards are increasingly important in food trade with developing countries, but the implications for smallholder farmers are still poorly understood. We analyze the implications of different coffee certification schemes in Ethiopia using cross-sectional survey data, and regression and propensity-score-matching techniques. We find that: Rainforest Alliance (RA) and double Fairtrade-Organic (FT-Org) certifications are associated with higher incomes and reduced poverty, mainly because of higher prices; Fairtrade (FT) certification hardly affects welfare; and Organic (Org) certification reduces incomes, chiefly due to lower yields. Cooperative heterogeneity importantly shapes these results. Results imply that private standards may not always deliver what they promise to consumers.
\end{abstract}

Keywords: private standards; sustainability standards; global value chains; coffee certification; poverty impact; Ethiopia

\section{Introduction}

Private sustainability standards (PSS) such as Fairtrade and Organic are increasingly common in the agri-food sector [1]. PSS are manifold and diverse, and focus to a varying extent on food quality and safety issues, social and ethical aspects, and environmental concerns of food production and trade [2]. PSS are usually set by private companies and non-state actors and enforced through third-party certification. PSS are mainly stipulated in high-income countries, as a response to changing consumer preferences and growing concerns about the quality, safety, ethics and environmental footprint of food production and trade. Yet, these standards are most important in the trade relations with developing countries-likely because of the incomplete information consumers have about product quality and production practices of producers in developing countries [3]—since studies often exclusively focus on, for example, Utz for coffee, cocoa and tea; $4 \mathrm{C}$ for coffee; and Fairtrade for other developing country products. Some standards make very specific claims and promises towards consumers. For instance, Fairtrade claims to "provide farmers with a better deal that allows them to improve their lives" and to "offer consumers a powerful way to reduce poverty through their everyday shopping" [4]. 
Likewise, Rainforest Alliance claims to "ensure the long-term economic health of forest communities through protecting ecosystems, safeguarding the well-being of local communities and improving productivity" [5].

It is far from a proven fact that PSS indeed improve farmers' wellbeing and contribute to poverty reduction. There is a growing body of literature investigating this issue, but the evidence is very mixed (see Beghin et al. [1] for a general review on standards in the food sector). Part of this literature focuses specifically on PSS in the coffee sector [6-22]. Some studies find that PSS enhance the welfare, productivity, income and food security of smallholder coffee producers, such as Fairtrade certification in India [20] and Peru [23]; Rainforest Alliance, Fairtrade and Organic certification in Nicaragua [21]; and Fairtrade, Organic and Utz certification in Uganda [12]. Another study also shows the positive effects of Fairtrade, Organic and Utz certification on gender equality with women having more control over coffee revenues in Uganda [13]. Other studies are less optimistic about the impact of PSS in the coffee sector, finding, for instance, that Fairtrade and Organic certifications do not contribute to poverty reduction in Nicaragua [8,14] and Ethiopia [18]. A study from Nicaragua and Guatemala indicates that producers gain relatively little from Fairtrade certification, while the largest gains go to consumer countries [24].

Understanding how PSS affect smallholder coffee producers in developing countries remains important. First, it is important from the perspective of smallholder producers themselves who face additional costs to fulfill stringent requirements to get certified, that standards contribute to improving their production systems, incomes and livelihoods. Second, it is important from the perspective of consumers in high-income countries who pay premium prices for specific attributes of the products or production processes of the food they consume. Standards are only genuine and premium prices only justified if they deliver on their promise to consumers. Third, it is important for standard-setting and certification bodies to know if the practices and standards they promote are effective. Fourth, it is important for the ongoing policy debate on the regulation and harmonization of private food standards to understand the impact of PSS on smallholder producers in developing countries [25].

In this paper, we analyze the implications of smallholder coffee certification in Ethiopia. We specifically look at four different certification schemes, including Fairtrade, Organic, double Fairtrade-Organic and Rainforest Alliance. We use cross-sectional survey data from a sample of 425 coffee farmers in the Jimma and Kaffa zones of Ethiopia. We specifically sampled certified and non-certified farmers who are members of a coffee cooperative linked to an export chain. By only focusing on cooperative members, we limit potential confoundedness arising from comparing certified farmers who are cooperative members and non-certified farmers who are not members of a cooperative- - as is often done in the literature. We use regression and propensity score-matching methods to analyze the impact of membership in a certified cooperative on poverty, income and yields.

This paper on the impact of smallholder coffee certification contributes to the literature in two ways. First, the focus on Ethiopia is particularly relevant because evidence on the impact of coffee certification in Africa is scarce. Apart from a very limited number of studies on Ethiopia [18], Kenya [22] and Uganda [12], studies on PSS in the coffee sector mainly focus on Latin-American countries. Ethiopia ranks first as coffee exporter among African countries and tenth worldwide, and the use of PSS in the Ethiopian coffee sector is increasing [26]. The coffee sector in Ethiopia still involves heavy state control, especially at the export level of the supply chain — contrary to Uganda where the coffee sector was largely liberalized and privatized. The impact of PSS on smallholder producers in such an institutional setting might differ from effects measured elsewhere. For example, the transmission of a price premium for certified produce to the producer level, might be more or less effective in a (partially) government-controlled supply chain. Second, our focus on different certification schemes in the same agro-ecological and institutional setting is relevant. Most studies on coffee certification focus on a single standard, including the study in Ethiopia on the impact of Fairtrade certification [18]. As standards differ widely in focus and requirements, their effectiveness in improving farmers' welfare and reducing poverty in specific settings may vary as well. A few studies have compared different 
standards [12,15,17,19,21,22]. For instance, Beuchelt and Zeller [15] and Ruben and Zuniga [21] compare different coffee certification schemes in Nicaragua and find that Rainforest Alliance has the largest income-enhancing effect while Fairtrade and Organic have no or only a very small impact on income and poverty. Chiputwa et al. [12] analyze the impact of Fairtrade, Organic and Utz certification in Uganda and find that only Fairtrade has a poverty-reducing effect. Van Rijsbergen et al. [22] find positive effects of Fairtrade and Utz certification in Kenya on smallholder coffee income and a larger effect of Utz on coffee productivity. There are no studies comparing different coffee certification schemes in Ethiopia.

\section{Background and Methods}

\subsection{The Coffee Sector in Ethiopia}

Ethiopia is the most important coffee-producing and -exporting country in Africa and the fifth most important coffee producer worldwide [27]. The sector accounts for $24 \%$ of total foreign exchange earnings [26] and provides a livelihood for more than a quarter of the country's population [28]. Over the period 1990-2013, coffee production in Ethiopia increased from 2.9 million bags (with one bag equivalent to $60 \mathrm{~kg}$ ) to 8.1 million bags; and exports increased from 0.85 to 3.2 million bags (Figure 1). Ethiopia has a specific coffee culture and tradition, and about $50 \%$ of production is consumed domestically (Figure 1). There is a difference in quality between coffee for the local market and export coffee. In an attempt to increase coffee exports and earnings, the government prohibits the sale of export quality coffee on the local market. The coffee sector in Ethiopia is largely a smallholder sector with $95 \%$ of production realized on small family farms with an average farm size of less than 2 ha [29], and the remainder on large plantations. In general, agro-chemical input use is not common among smallholder coffee producers in Ethiopia, with an estimated $6 \%$ of producers using chemical fertilizer and $2 \%$ using pesticides or other agro-chemicals [30]. There are more than 4 million coffee-producing farm-households in the country and coffee contributes to up to $50 \%$ of total income for these households [31]. A substantial share of smallholder coffee farmers is organized in cooperatives-there are 465 primary coffee cooperatives in the country—but independent smallholder coffee production is also common.

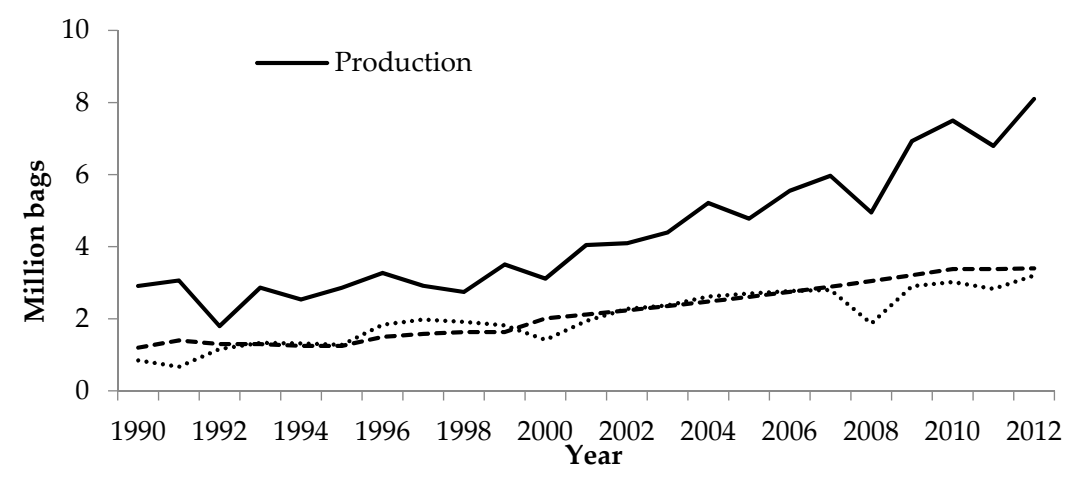

Figure 1. Coffee production, domestic consumption and export, million bags (with one bag equivalent to $60 \mathrm{~kg}$ ) in Ethiopia, 1990-2012. Source: Author's computation based on data from the International Coffee Organization (http://www.ico.org/new_historical.asp).

Ethiopian coffee is exported through three channels: (1) a private sector supply chain; (2) a supply chain including parastatal firms; and (3) a supply chain including cooperatives and cooperative unions. Due to structural reforms and the gradual privatization of state farms since 1991, the share of coffee exported by cooperative unions and the private sector is increasing while that of parastatal firms is decreasing [26]. The Ethiopian Commodity Exchange (ECX) was established in 2008 to control coffee quality and facilitate marketing. ECX sets requirements for quality and grading systems, transaction 
size, and payment and delivery modalities. Almost all coffee destined for export is sold on the ECX floor. Yet, cooperative unions and private producer-exporters are allowed to export directly; in which case ECX only grades the coffee [28]. Export taxes were removed after the 2002 coffee crisis [26] but the government still intervenes in the sector through export bans for large private traders who excessively hoard coffee (more than 500 ton) without having a shipment contract with importers. Value-adding in the coffee sector is low: only 30\% of export coffee is sold as washed coffee [26]. Washed and unwashed coffee beans are graded based on cup tests and physical inspection from 1 to 5 , with 1 representing the highest quality and 5 the lowest. Grades 1 and 2 are usually assigned to washed coffee, grades 3 to 5 to unwashed coffee and coffee falling outside the grades are rejected for export [26].

PSS started to emerge in the coffee sector in southwestern Ethiopia in the early 2000s [32]. Certification to PSS is mainly cooperative-based and currently $29 \%$ of primary coffee cooperatives are Organic certified, 27\% Fairtrade, and 2\% Rainforest Alliance or Utz-resulting in about 5\% of coffee exported as certified coffee [30]. Minten et al. [26] estimate the price premium for Fairtrade (FT) and Organic (Org) certified Ethiopian coffee to be, on average, $9 \%$ of the conventional price at export level over the period 2006-2013, of which only a third is transmitted to farmers [30]. In this paper, we focus on Org, FT, double Fairtrade-Organic (FT-Org) and Rainforest Alliance (RA) certification. As RA focuses more (but not exclusively) on environmental issues such as biodiversity conservation, Org on organic production methods, and FT on producer welfare and empowerment; we expect to find the largest income enhancing and poverty-reducing effects of FT certification.

\subsection{Data Collection}

We collected original data from Southwestern Ethiopia through a farm-household survey and through semi-structured interviews with coffee cooperatives and key informants. Data were collected in 2014. A multi-stage stratified random sampling strategy was used. We first purposively selected four districts (woredas) in the adjacent Kaffa and Jimma zones, where Coffea arabica originates and where the first certification schemes emerged in 2005. The two zones are similar in biophysical and socioeconomic characteristics. We then listed all coffee cooperatives in these districts and stratified them according to certification scheme, including RA certified, FT certified, Org certified, double FT-Org certified and non-certified cooperatives. In order to sample certified and non-certified cooperative members from the same district, we randomly selected one certified cooperative in each district and one non-certified cooperative in all but one district, because in one district we could not identify a non-certified coffee cooperative. Our sample includes seven cooperatives of which four are certified, each to a different scheme, and three are not certified (Table 1). Finally, we randomly selected farmers from the cooperative member lists. Farmers in a certified cooperative are usually all certified. To construct a good control group, we purposefully oversampled farmers from non-certified cooperatives relative to the total membership. The final sample includes 425 households, including 270 certified coffee farmers and 155 non-certified coffee farmers (Table 1). This sample size is comparable with previous studies that compare the impact of different standards [12,21].

Table 1. Sample design.

\begin{tabular}{cccccc}
\hline Zone & District & Cooperative & Certification Status & Members & Sample \\
\hline \multirow{2}{*}{ Jimma } & Shebe Sombo & A & Rainforest Alliance & 550 & 81 \\
\hline \multirow{3}{*}{ Kaffa } & \multirow{2}{*}{ Decha } & B & Organic & 508 & 63 \\
& \multirow{2}{*}{ Gimbo } & C & Non-certified & 105 & 49 \\
\cline { 2 - 6 } & \multirow{2}{*}{ Gowata } & D & Fairtrade and Organic & 446 & 64 \\
& & F & Non-certified & 44 & 41 \\
\hline \multirow{2}{*}{ Total } & G & Fairtrade & 188 & 62 \\
& \multirow{5}{*}{ Source: Authors' computation from data collected at cooperative level. } &
\end{tabular}


The survey was implemented using a structured questionnaire, consisting of detailed modules on: (i) household characteristics; (ii) child labor and schooling; (iii) land ownership and use; (iv) coffee production and marketing; (v) other crop production; (vi) livestock ownership and production; (vii) forest use; (viii) off-farm income; (ix) asset ownership and living conditions; (x) social capital and credit; and (xi) decision making. It should be noted that quantitative survey data collection among farm-households is common in agricultural and development economics. We have followed standard procedures in developing the questionnaire and in implementing the survey in the field, with a team of well-trained enumerators and several survey coordinators. Survey data are prone to measurement error and imprecision but we do not see any reasons for systematic measurement error in our data that could lead to biased results. Semi-structured interviews were carried out with cooperative committees, district officials, officials from the coffee unions and some coffee experts.

\subsection{Econometric Approach}

To assess the impact of certification to different standards on the welfare of farm-households, we estimate regression models of the following type:

$$
Y_{i}=\alpha_{0}+\beta X_{i}+\gamma T_{i}+\varepsilon_{i}
$$

where $Y_{i}$ measures the welfare outcome of household $i, X_{i}$ a vector of control variables, $T_{i}$ our treatment variable and $\varepsilon_{i}$ the idiosyncratic error term; $\alpha, \beta$ and $\gamma$ are parameters to be estimated. We are primarily interested in estimating the impact on poverty, but to understand the channels through which poverty effects possibly occur, we include additional outcome indicators. We use the following four outcome indicators and estimate the model separately for each indicator: (1) coffee yield, measured as the dry cherry equivalent in kg per ha; (2) coffee income, measured as the log of net income from coffee production (i.e., this is net coffee income, calculated as the difference between coffee revenue-coffee produced $\times$ coffee price - and coffee-related variable costs-hired labor, transportation, certification, seedling material and seedling transportation); (3) household income, measured as the log of total household income (i.e., household income is composed of farm income-including income from coffee, other crops and livestock rearing-and off-farm income-including income from wage work, non-farm self-employment, collection and gathering of forest products and income transfers, whereas income includes cash income as well as income from subsistence agricultural production and collection of forest products, valued at market prices); and (4) poverty, measured as a binary variable for having a per capita income that falls below the national poverty line (we use the national poverty line of Ethiopia, equaling 3781 ETB (Ethiopian Birr) per adult equivalent per year [33].). For the first three dependent variables, which are continuous, we use a linear regression model and ordinary least squares estimation while for the latter binary variable, we use a probit estimation. The income variables are log-specified in order to reduce the impact of potential influential observations and to be able to interpret results directly in percentage terms. For all models, we report heteroskedasticity-robust standard errors (sandwich variance estimators); and for the probit model, we report marginal effects at the sample means.

Our main variable of interest is $T_{i}$, a vector of mutually exclusive binary variables for certification to FT, Org, FT-Org and RA standards. Non-certified farmers are used as control group. Membership in a certified cooperative is likely not randomly distributed among coffee farmers. We therefore include a large vector of observable farmer characteristics, $X_{i}$. We include variables reflecting different forms of capital ownership that are selected based on standard micro-economic theory as reflected in the sustainable livelihoods framework [34,35]. Different forms of capital of a household, including human, natural, physical, social and financial capital, along with household preferences, determine the livelihood strategies of a household and the welfare outcome of these strategies. We include the following variables in the vector $X_{i}$ : gender, age and education of the household head; household size and number of dependents; total land ownership (in the models on total income and poverty) or 
coffee area, coffee age and coffee tree density (in the models on coffee yield and income) and respective squares; livestock ownership (measured in tropical livestock units); the number of relatives in the region (as a measure of social capital; i.e. this indicator concerns the number of relatives in the region with whom a household has a relationship. With quantitative survey data, it is difficult to measure social capital in all its dimensions and from our data, only this indicator of social capital is available. Although this indicator does not capture different components or different forms of social capital, it at least allows controlling for differences in social relations among coffee farmers to some extent); number of years a farmer stayed in a cooperative; and distance to the district town. We are unable to control for other observable and unobservable factors that may affect farmer's self-selection into a certified cooperative and their welfare outcome. Given that we cannot identify valid instruments, we refrain from an instrumental variable estimation to control for selection bias and unobserved heterogeneity. In addition, it is particularly difficult to single out the effect of certification from the effect of membership in specific cooperatives and from the location of farmers because villages usually only include one coffee cooperative and members of a specific cooperative are usually either all certified or all not certified.

As an alternative method to control for potential selection bias, we additionally estimate the impact of membership in a certified cooperative using propensity score matching (PSM) [36] combined with a sensitivity analysis that tests the assumption of selection on observables. We estimate the average treatment effect (ATE) of certification to the four different certification schemes on the four outcome indicators. We first estimate the propensity scores (PS), or the probability a household is a member of a certified cooperative, using a series of probit models for the four mutually exclusive treatments/certification schemes. In this model, we only include variables that are not possibly influenced by the treatment or certification [37]: gender, age and education of the household head; household size and number of dependents; total land ownership; livestock ownership; the number of relatives in the region (as a measure of social capital); and distance to the district town. Multiple binary models were chosen in favor of multinomial PS models as the latter are computationally more demanding and are considered less robust as a misspecification in one equation could render all other conditional estimates inconsistent [38]. We then matched households using a kernel matching method with the default Gaussian kernel. This allows use of information from all non-certified/control households and a weighting function to construct the counterfactual outcome, and reduces variance [37]. After matching, we estimate the ATE as the weighted difference between treated and matched control households using bootstrapped standard errors.

The validity of PSM relies on two essential assumptions. First, the common support or overlap condition requires that treatment observations have comparison control observations nearby in the propensity score distribution [37]. We only use observations in the common support region (i.e., where the PS of treated observations is not lower than the PS of control observation and the PS of control observations is not larger than the PS of treated observations). We visually compare overlap in the propensity score distribution between certified and non-certified observations. We further assess balancing properties by comparing covariate means between treated and matched controls using two-sided $t$-tests. Overall balancing properties are further tested by re-estimating the propensity score on the matched sample and looking at the Pseudo $R^{2}$ — which should be low-and performing a likelihood ratio test on the joint significance of all regressors-which should be rejected [37]. Second, the conditional independence assumption requires that given observable variables, potential outcomes are independent of treatment assignment $[39,40]$. This implies that selection into treatment is based entirely on observable covariates, which is a strong assumption. We test the robustness of our results against violation of this assumption, using a simulation-based sensitivity analysis as proposed by Ichino et al. [41]. The method simulates a binary confounder to mimic a possible unobserved influential factor and compares these PSM results with the baseline results. The data were analyzed by STATA software version 14 (StataCorp, College Station, TX, USA). 


\section{Results}

\subsection{Cooperative Characteristics}

In Table 2, we present summary statistics for the seven sampled cooperatives, including information for the current situation (survey year 2014) and for the initial situation before certification began (year 2004). The sampled cooperatives are very heterogeneous: the year of establishment ranges from 1999 to 2011; the cooperative size varies from 44 to 550 members; the entry fee from 60 to 600 ETB; the supply capacity from 4.5 to 214 tons in which the share of dry coffee cherry varies from $6 \%$ to 100\%; and the capital stock from 69 to 2800 thousand ETB. The certified cooperatives all became certified in 2005 and were hence certified for nine years at the time of data collection, except for the RA-certified cooperative becoming certified upon its foundation in 2007. All cooperatives have coffee storage facilities and offer training to their members, but only three cooperatives own a washing station. During the period 2004-2014, all cooperatives increased in size, both in terms of members and supply capacity, and increased their capital stock and entrance fee-but the magnitude of these changes varies substantially over the individual cooperatives. Only three cooperatives paid dividends to their members the last year with the average dividend payments ranging from 158 ETB to 1127 ETB. The others paid the most recent dividend two to four years ago, and the most recently established cooperative (E) did not yet pay any dividend.

Table 2. Characteristics of sampled cooperatives.

\begin{tabular}{|c|c|c|c|c|c|c|c|}
\hline \multirow{2}{*}{ Variable (Units) } & \multicolumn{7}{|c|}{ Cooperative } \\
\hline & A & B & $\mathrm{C}$ & $\mathbf{D}$ & $\mathbf{E}$ & F & G \\
\hline Certification scheme & RA & Org & None & FT-Org & None & FT & None \\
\hline Year of establishment & 2007 & 2000 & 2003 & $1999^{\circ}$ & 2011 & 2001 & 2004 \\
\hline Year of certification & 2007 & 2005 & - & 2005 & - & 2005 & - \\
\hline \multicolumn{8}{|l|}{ Initial situation of cooperatives in 2004} \\
\hline \multicolumn{8}{|l|}{ Cooperative size (\# members) } \\
\hline Total & - & 42 & 12 & 210 & - & 44 & 60 \\
\hline Female members & - & 4 & 0 & 76 & - & 1 & 0 \\
\hline Entry fee (ETB) & - & 42 & 120 & 102 & - & 42 & 31 \\
\hline Coffee supplied (ton/year) & - & 2.64 & 0.76 & 21.69 & - & 2.23 & 4.62 \\
\hline Capital $\left(10^{3}\right.$ ETB $)$ & - & 2.36 & 25 & 37.4 & - & 4 & 1.86 \\
\hline \multicolumn{8}{|l|}{ Current situation of cooperatives in 2014} \\
\hline \multicolumn{8}{|l|}{ Cooperative size (\# members) } \\
\hline Total & 550 & 508 & 105 & 446 & 44 & 188 & 124 \\
\hline Female members & 96 & 129 & 8 & 76 & 4 & 4 & 2 \\
\hline Entry fee (ETB) & 300 & 250 & 160 & 600 & 360 & 150 & 60 \\
\hline Coffee supplied (ton/year) & 214.4 & 65 & 6.3 & 86.87 & 4.53 & 9.8 & 8.65 \\
\hline Share of dry coffee supplied (\%) & 45.63 & 5.84 & 100 & 20.42 & 100 & 100 & 100 \\
\hline Capital $\left(10^{3}\right.$ ETB $)$ & 2800 & 1583 & 151 & 1000 & n.a. & 69 & 147 \\
\hline Number of washing stations owned & 1 & 1 & 0 & 2 & 0 & 0 & 0 \\
\hline Own coffee storage & Yes & Yes & Yes & Yes & Yes & Yes & Yes \\
\hline Provision of training to members & Yes & Yes & Yes & Yes & Yes & Yes & Yes \\
\hline Last year of dividend payment & 2014 & 2014 & 2010 & 2014 & n.a. & 2012 & 2010 \\
\hline Average amount of dividend (ETB) & 1127.40 & 279.16 & 114.23 & 158.50 & n.a. & 15.13 & 181.2 \\
\hline
\end{tabular}

n.a. = not available; RA: Rainforest Alliance; Org: Organic; FT: Fairtrade; ETB: Ethiopian Birr. Information on the initial situation for 2004 of cooperatives A and E is not applicable (indicated with "-") as these were only established in 2007 and 2011, respectively. Source: Authors' calculation from survey and interview data.

Cooperatives A, B and D seem to be the best-performing cooperatives with the highest membership, largest capital stock, largest coffee supply, most recent and largest dividend payments and their own washing stations. The latter is important as it increases the value-added and quality of coffee. Farmers in these cooperatives can supply fresh cherries to the cooperatives where the coffee cherries are washed (with timing between coffee picking and washing being important for quality) or dried coffee. The share of higher quality washed coffee supplied by cooperatives A, B and D in 2014 was $54.4 \%, 94.2 \%$ and $79.5 \%$, respectively (please note that cooperatives are not aware of how 
the coffee they supply to the cooperative union is graded by ECX. Cooperative unions mix coffee supplied from different cooperatives before grading, which makes it impossible to reveal quality information at the cooperative-and farmer-level). These better-performing cooperatives are RA-, Organd FT-Org-certified cooperatives. Compared to these, the FT-certified cooperative (F) is relatively small in terms of members, coffee supply, capital stock and dividend payment; and is the only certified cooperative without its own washing station. Not having a washing station implies that farmers dry the coffee cherries after picking and sell their coffee as a lower quality dry-processed coffee. While the RA-, Org- and FT-Org-certified cooperatives are clearly distinct from the others, the FT-certified cooperative is more similar to the non-certified cooperatives, which are also smaller and less capitalized.

\subsection{Household Characteristics}

In Table 3, we present household-level summary statistics and compare these for members of certified and non-certified cooperatives. In general, most sampled households are male-headed (92\%); average age of the head is 45 years and average years of schooling 3.55 years; family size is rather large with an average of 3.4 workers and 3.5 dependents. Farm size is, on average, 2.84 ha and livestock ownership 4.66 units. Farmers are members of a coffee cooperative for an average of 7.4 years and a member of a certified cooperative for, on average, 5.3 years. Distance to the market is, on average, $73 \mathrm{~min}$. There are some significant differences between certified and non-certified cooperative members-most notably, certified coffee farmers are located closer to the district town than non-certified farmers.

Table 3. Characteristics of sampled households, according to certification scheme.

\begin{tabular}{|c|c|c|c|c|c|c|}
\hline \multirow{2}{*}{ Variables (Unit) } & \multirow{2}{*}{$\begin{array}{c}\text { Total } \\
\text { Sample }\end{array}$} & \multirow{2}{*}{$\begin{array}{c}\text { Members of Non-Certified } \\
\text { Cooperatives }\end{array}$} & \multicolumn{4}{|c|}{ Members of Certified Cooperatives } \\
\hline & & & FT & Org & FT-Org & RA \\
\hline \multicolumn{7}{|l|}{ Human capital } \\
\hline $\begin{array}{l}\text { Female household head } \\
\text { (dummy) }\end{array}$ & $\begin{array}{c}0.08 \\
(0.12)\end{array}$ & $\begin{array}{c}0.06 \\
(0.02)\end{array}$ & $\begin{array}{c}0.06 \\
(0.03)\end{array}$ & $\begin{array}{c}0.08 \\
(0.03)\end{array}$ & $\begin{array}{l}0.16^{*} \\
(0.05)\end{array}$ & $\begin{array}{c}0.05 \\
(0.02)\end{array}$ \\
\hline $\begin{array}{l}\text { Age household head } \\
\text { (years) }\end{array}$ & $\begin{array}{l}45.57 \\
(0.70)\end{array}$ & $\begin{array}{l}46.60 \\
(1.10)\end{array}$ & $\begin{array}{l}47.28 \\
(1.98)\end{array}$ & $\begin{array}{l}44.56 \\
(2.03)\end{array}$ & $\begin{array}{l}48.05 \\
(1.80)\end{array}$ & $\begin{array}{c}41.13^{* * *} \\
(1.45)\end{array}$ \\
\hline $\begin{array}{l}\text { Education household head } \\
\text { (years) }\end{array}$ & $\begin{array}{c}3.55 \\
(0.16)\end{array}$ & $\begin{array}{c}3.72 \\
(0.29)\end{array}$ & $\begin{array}{l}2.87^{*} \\
(0.45)\end{array}$ & $\begin{array}{l}2.89 * \\
(0.38)\end{array}$ & $\begin{array}{c}4.39 \\
(0.47)\end{array}$ & $\begin{array}{c}3.59 \\
(0.33)\end{array}$ \\
\hline Adults in household (no.) & $\begin{array}{l}3.39 \\
(0.08)\end{array}$ & $\begin{array}{c}3.69 \\
(0.13)\end{array}$ & $\begin{array}{c}3.32 \\
(0.19)\end{array}$ & $\begin{array}{l}3.08^{* * *} \\
(0.19)\end{array}$ & $\begin{array}{l}3.30 * \\
(0.19)\end{array}$ & $\begin{array}{l}3.17^{* *} \\
(0.18)\end{array}$ \\
\hline $\begin{array}{l}\text { Dependents in household } \\
\text { (no.) }\end{array}$ & $\begin{array}{c}3.54 \\
(0.10)\end{array}$ & $\begin{array}{c}4.00 \\
(0.18)\end{array}$ & $\begin{array}{c}3.52 \\
(0.26)\end{array}$ & $\begin{array}{l}3.33^{* *} \\
(0.24)\end{array}$ & $\begin{array}{c}2.81^{* * *} \\
(0.22)\end{array}$ & $\begin{array}{l}3.41^{* *} \\
(0.25)\end{array}$ \\
\hline \multicolumn{7}{|l|}{ Physical Assets } \\
\hline Total area (ha) & $\begin{array}{c}2.84 \\
(0.14)\end{array}$ & $\begin{array}{c}2.99 \\
(0.31)\end{array}$ & $\begin{array}{l}2.76 \\
(0.19)\end{array}$ & $\begin{array}{c}2.94 \\
(0.33)\end{array}$ & $\begin{array}{c}3.30 \\
(0.40)\end{array}$ & $\begin{array}{l}2.17^{* *} \\
(0.20)\end{array}$ \\
\hline Livestock (TLU) & $\begin{array}{l}4.66 \\
(0.17)\end{array}$ & $\begin{array}{c}6.28 \\
(0.34)\end{array}$ & $\begin{array}{c}4.37^{* * *} \\
(0.35)\end{array}$ & $\begin{array}{l}4.34^{* * *} \\
(0.36)\end{array}$ & $\begin{array}{l}3.90^{* * *} \\
(0.28)\end{array}$ & $\begin{array}{c}2.66^{* * *} \\
(0.32)\end{array}$ \\
\hline \multicolumn{7}{|l|}{ Social capital } \\
\hline Relatives (no.) & $\begin{array}{l}48.88 \\
(4.15) \\
\end{array}$ & $\begin{array}{l}30.12 \\
(2.30)\end{array}$ & $\begin{array}{l}23.94 \\
(2.89)\end{array}$ & $\begin{array}{c}45.86^{* *} \\
(5.61)\end{array}$ & $\begin{array}{l}128.13^{* * *} \\
(22.83)\end{array}$ & $\begin{array}{c}43.58^{* * *} \\
(5.88)\end{array}$ \\
\hline Years coop member (years) & $\begin{array}{c}7.38 \\
(0.27)\end{array}$ & $\begin{array}{c}8.88 \\
(0.52)\end{array}$ & $\begin{array}{c}9.69 \\
(0.62)\end{array}$ & $\begin{array}{l}6.14^{* * * *} \\
(0.70)\end{array}$ & $\begin{array}{l}7.00 * * \\
(0.70)\end{array}$ & $\begin{array}{l}3.99 * * * \\
(0.17)\end{array}$ \\
\hline $\begin{array}{c}\text { Years exposed to } \\
\text { certification (years) }^{a}\end{array}$ & $\begin{array}{c}5.34 \\
(0.16)\end{array}$ & - & $\begin{array}{l}7.06 \\
(0.36)\end{array}$ & $\begin{array}{l}5.17 \\
(0.32)\end{array}$ & $\begin{array}{c}5.56 \\
(0.33)\end{array}$ & $\begin{array}{l}3.99 \\
(0.17)\end{array}$ \\
\hline \multicolumn{7}{|l|}{ Village infrastructure } \\
\hline $\begin{array}{l}\text { Distance to district town } \\
\text { (min) }\end{array}$ & $\begin{array}{l}73.58 \\
(3.57)\end{array}$ & $\begin{array}{l}105.98 \\
(8.45)\end{array}$ & $\begin{array}{l}81.52 * * \\
(7.11)\end{array}$ & $\begin{array}{l}39.13^{* * *} \\
(2.00)\end{array}$ & $\begin{array}{c}55.94^{* * * *} \\
(2.99)\end{array}$ & $\begin{array}{c}46.23^{* * *} \\
(2.07)\end{array}$ \\
\hline Number of observations & 425 & 155 & 62 & 63 & 64 & 81 \\
\hline
\end{tabular}

a Years exposed to certification: mean number of years farmers have been in a cooperative after certification was introduced. The total sample refers to the sub-sample of certified cooperative members only. Comparisons are made between certified and non-certified households for the four categories of certificates using one-sided $t$-tests. Figures in parentheses are standard errors. ${ }^{*} p<0.1,{ }^{* *} p<0.05,{ }^{* * *} p<0.01$. Source: Authors' calculation from own survey data. 


\subsection{Coffee Production, Income and Poverty}

In Table 4, we present information on coffee production (area and inputs), coffee management practices, coffee prices (for fresh and dry coffee cherries), coffee yield, coffee income, total household income and poverty incidence; making a comparison between members of certified and non-certified cooperatives. Farmers in our study area allocate, on average, $36 \%$ of their land to coffee production and plant about 3500 coffee shrubs per ha. Coffee age is, on average, about 13 years. They use a negligible amount of chemical fertilizer and pesticides, resulting in low capital costs per ha. The use of chemical fertilizers, pesticides and herbicides is extremely low in the study area, but farmers do use animal manure $(47 \%)$ and compost $(19 \%)$. Weed management is done manually by $87 \%$ of the farmers; slashing the undergrowth by $72 \%$ and tilling the land by $38 \%$.

Table 4. Characteristics of coffee production, household income and poverty incidence across households in different certification schemes.

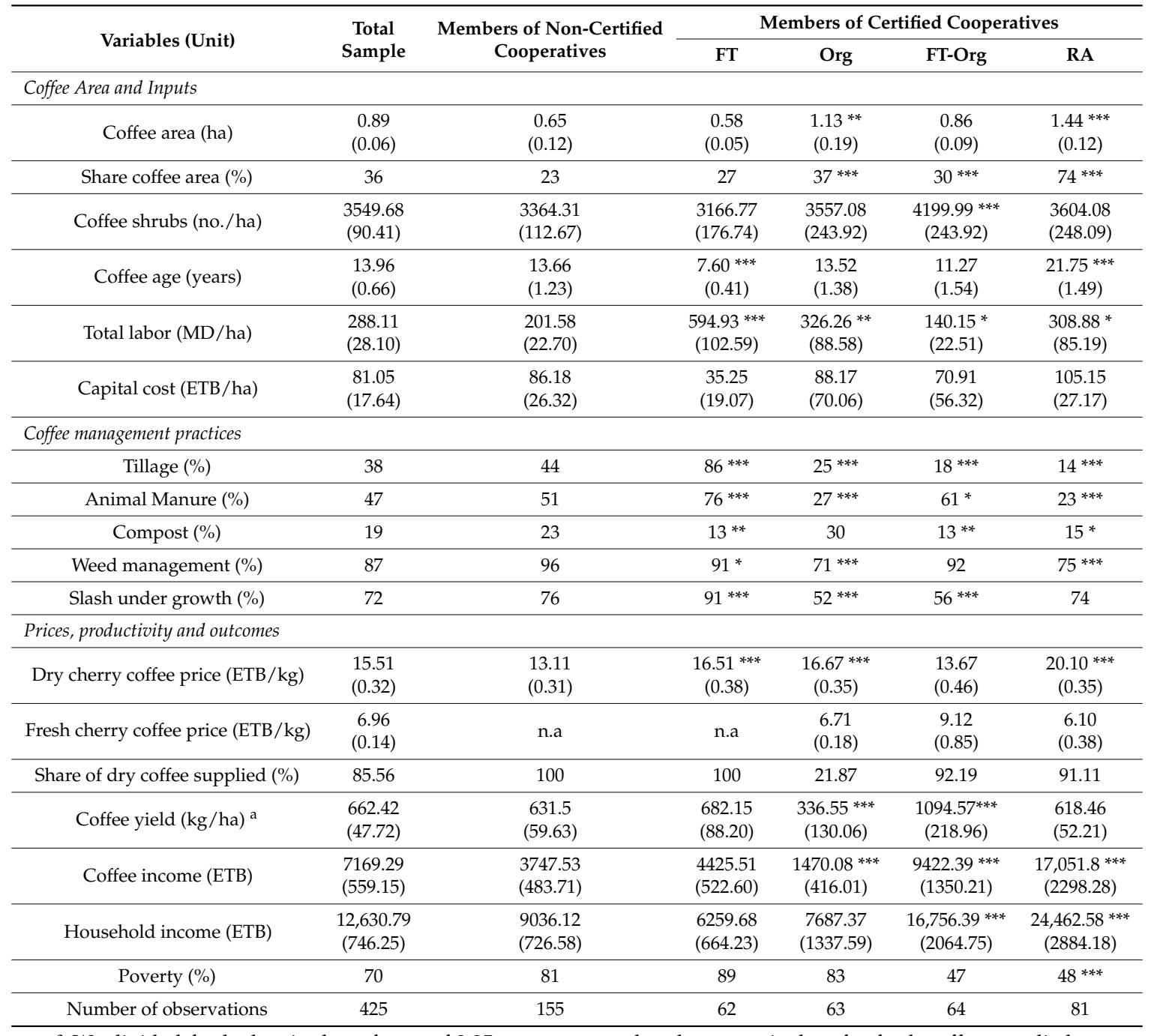

${ }^{a}$ We divided fresh cherries by a factor of 2.25 to convert to dry cherry equivalent for fresh coffee supplied to cooperatives (the conversion factor is based on an expert interview). Comparisons are made between certified and non-certified households for the four categories of certificates using one-sided $t$-tests. ${ }^{*} p<0.1,{ }^{* *} p<0.05$, *** $p<0.01$. Figures in parentheses are standard errors. MD: man-day; Capital cost includes costs such as cost of certification at households level, the cost of pesticides and herbicides if any. Share of coffee area is calculated as coffee area divided by total area. Labor is given in adult labor equivalent. Mean price for fresh cherry over the total sample is calculated from the sub sample of households that have sold fresh coffee. Source: Authors' calculation from survey data (2014). 
We observe important differences in coffee management practices and intensity of coffee production among members of certified and non-certified cooperatives. Members of the FT-certified cooperative have younger coffee shrubs that require more care and are more likely to till the soil $(86 \%)$, to apply animal manure $(76 \%)$, to manually weed $(91 \%)$ and slash the undergrowth $(91 \%)$ than the non-certified farmers. Moreover, they supply only dried coffee as the FT cooperative does not have a washing station. Drying coffee in accordance with standard requirements includes carefully constructing beds and using mats for coffee drying and timely handling during the drying process; which is relatively labor intensive. Labor-intensive cultivation and drying practices among FT farmers-which are only to some extent directly related to certification requirements-result in an average labor use per ha of coffee that is about three times as high as labor use among non-certified farmers. Org-certified farmers have, on average, a larger coffee area and a higher importance of coffee in total land use, and are less likely apply tillage (25\%), animal manure $(27 \%)$, weed management $(71 \%)$ and slash undergrowth $(52 \%)$ than non-certified farmers. They, however, use more labor per ha compared to non-certified farmers but substantially less than FT farmers. Farmers in the FT-Org-certified scheme cultivate their coffee area most intensively with, on average, 4200 coffee shrubs per ha but use the least labor per ha as they are less to likely apply tillage (18\%), compost $(13 \%)$ and slash undergrowth (56\%). RA-certified farmers are specialized in coffee production with an average of $74 \%$ of their land allocated to coffee and the largest average coffee area, but their coffee shrubs are significantly older. They use more labor than non-certified farmers mainly to dry their coffee to the RA standards. RA certifies only (semi-)forest coffee, whereas households produce also garden coffee which does not qualify according to RA criteria and is hence not certified (please note that this is because there are four coffee production systems in Ethiopia: forest, semi-forest, garden and plantation. Forest coffee is collected from undisturbed natural forest; semi-forest coffee is produced in managed forest; garden coffee is produced in a household's homestead either with scattered shade trees and/or in intercropped with other crops; and plantation coffee is cultivated and intensively managed by investors). RA accepts and pays a premium only for dry (semi-)forest coffee cherries while farmers can still sell their fresh coffee from semi-(forest) and garden to the cooperative, though this coffee does not end up in the supply chain as RA-certified coffee.

The average farm-gate price for dry coffee is $15.5 \mathrm{ETB} / \mathrm{kg}$. As all farmers supply dry coffee from time to time-even those farmers in cooperatives with a washing station supply-we can compare the price for dry coffee across farmers. In all certification schemes, farmers receive a significantly higher price for dry coffee than non-certified farmers, except for farmers in the FT-Org scheme for which no significant difference is observed. RA farmers receive the highest price $(20 \mathrm{ETB} / \mathrm{kg}$ on average), followed by FT farmers and Org farmers (about $16.5 \mathrm{ETB} / \mathrm{kg}$ on average). FT-Org farmers do not receive a higher price for dry coffee but they do receive the highest price for fresh coffee cherries. Comparing prices for wet coffee cherries is more difficult as not all farmers sell fresh coffee cherries-i.e., only when cooperatives own a washing station can farmers supply fresh cherries. Only Org, FT-Org and RA supply fresh cherries and receive an overall average price of $7 \mathrm{ETB} / \mathrm{kg}$. FT-Org farmers receive the highest fresh coffee cherry price $(9.12 \mathrm{ETB} / \mathrm{kg})$, which is $28 \%$ above the price that Org and RA farmers receive for fresh coffee cherries. The observed differences in prices reveal that all certified farmers receive higher farm-gate prices; for FT, Org and RA farmers, higher prices apply to dried coffee, whereas for FT-Org farmers, higher prices apply to fresh coffee. We need to note that prices reflect eventual price premia for certified coffee as well as possible differences in coffee quality - as no information on coffee quality is available at farmer or cooperative level, we are unable to further distinguish quality differences from certification premia.

On average, $85.6 \%$ of the coffee supplied to cooperatives is dry coffee; non-certified farmers and FT farmers supply 100\% dry coffee, whereas Org, FT-Org and RA farmers supply $22 \%, 92 \%$ and 91\% dry coffee, respectively (Table 4). From cooperative level interviews, it appears that the FT-Org cooperative pays a higher price for fresh coffee to encourage farmers to supply more fresh cherries so that it can better use the capacity of its two washing stations, whereas the Org cooperative pays 
a higher price for dry coffee to encourage home dry processing to reduce the burden on its single washing station.

The average coffee yield in the sample is $662 \mathrm{~kg}$ dry cherry equivalent per hectare; Org farmers have the lowest yield ( $337 \mathrm{~kg} / \mathrm{ha}$ on average) and FT-Org-certified farmers have the highest yield $(1095 \mathrm{~kg} / \mathrm{ha})$. The high yield for FT-Org farmers is likely related to the fact that the coffee tree density on their plots is higher, combined with coffee shrubs of an intermediate and more productive age (younger than the average age of coffee trees for RA farmers but older than the average age of coffee trees for FT farmers). For other farmers, yields are comparable: an average of $631 \mathrm{~kg} / \mathrm{ha}$ for non-certified farmers, $682 \mathrm{~kg} / \mathrm{ha}$ for FT farmers and $618 \mathrm{~kg} / \mathrm{ha}$ for RA farmers. The net coffee income in the sample is, on average, 6899 ETB. There is substantial variation in coffee income across farmers, with the largest coffee income among RA farmers (17,051 ETB) and the lowest among Org-certified farmers (1470 ETB). Average household income in the sample is 12,534 ETB. It is the largest among RA-certified farmers (24,463 ETB), followed by FT-Org-certified farmers (16,756 ETB). Household income for Org farmers is comparable to that of non-certified farmers, while for FT farmers, household income is the lowest. Apart from coffee production that accounts, on average, for $55 \%$ of household income, farmers in the area derive income from other crops $(29 \%)$ and livestock rearing $(11 \%)$. Income from non-farm sources is very limited (4.7\%). For Org farmers, an average of only $19 \%$ of income comes from coffee production, while for the other farmers, this is between $41 \%$ and $70 \%$. There is a high incidence of poverty in our study area with $71 \%$ of the sampled households falling below the national poverty line. This is much higher than the incidence of poverty at the national level that is estimated at $29.6 \%$ for 2011 [33], but consistent with an estimated poverty incidence of $86 \%$ in our study area in 2009 [18]. The incidence of poverty is lowest among FT-Org- and RA-certified households, respectively $47 \%$ and $48 \%$.

\subsection{Econometric Results}

We summarize the main results in Table 5: the estimated effects of membership in FT-, Org-, FT-Org- and RA-certified cooperatives on coffee yields, coffee income, total household income and poverty. We report the main regression results along with the estimated treatment effects from the propensity score matching. The results from the regression analysis and PSM largely point in the same direction, which is an indication of the robustness of the results. The full regression results are reported in Table A1 and the results from the PS estimation in Table A2 in the Appendix A. Based on the propensity score distribution in Figure 2 and the balancing properties in Table A3, we can conclude that there are no major problems with the assumption of common support. Balancing properties are satisfied with balancing between certified and matched control observations for all covariates and all treatment groups of certified farmers-with no significant differences at the $5 \%$ level. In addition, overall balancing is satisfied for all samples as the pseudo $R^{2}$ of the matched samples are very low (below $5 \%$ ) and the $\mathrm{Chi}^{2}$ likelihood ratio tests on the joint significance of all regressors in the matched sample probit models are rejected. Table A4 presents the results of the simulation-based sensitivity analysis testing robustness to violations of the conditional independence $(\mathrm{CI})$ assumption. The results show that, with a neutral confounder, the estimates deviate between 0.6 and $7.5 \%$ from the original estimates. We find the highest deviation for the effect of FT certification on income (15.3\%) and the effect of RA certification on coffee yield (50.5\%), indicating these results are least robust to failure of the $\mathrm{CI}$ assumption. Below, we describe the results for the different certification schemes and discuss these in the next section.

First, for participation in a FT cooperative, we only find a positive significant effect on coffee income. The magnitude of the estimated effect implies that membership in a FT cooperative more or less doubles coffee income. The other estimated effects on coffee yield, household income and poverty are not significant. These estimates, along with the fact that the farm-gate coffee price is significantly higher for FT-cooperative members than for members of non-certified cooperatives (Table 4), indicate that membership in a FT cooperative improves coffee income through a price effect and not through a yield effect. In addition, the observed effect on coffee income does not translate into an overall positive 
effect on household income and a reduction in poverty. This lack of an effect on total income likely stems from the fact that for FT cooperative members, coffee uses labor quite intensively (Table 4) such that less labor is available for other farm and non-farm activities.

Table 5. Mean comparison and estimated effects of participation in Fairtrade-, Organic-, Fairtrade and Organic-, and Rainforest Alliance-certified cooperatives on coffee yield, coffee income, household income and poverty.

\begin{tabular}{ccccccccc}
\hline \multirow{2}{*}{$\begin{array}{c}\text { Outcome } \\
\text { Variables }\end{array}$} & \multicolumn{2}{c}{$\begin{array}{c}\text { FT-Certified } \\
\text { Cooperative }\end{array}$} & \multicolumn{2}{c}{$\begin{array}{c}\text { Org-Certified } \\
\text { Cooperative }\end{array}$} & \multicolumn{2}{c}{$\begin{array}{c}\text { FT-Org-Certified } \\
\text { Cooperative }\end{array}$} & \multicolumn{2}{c}{$\begin{array}{c}\text { RA-Certified } \\
\text { Cooperative }\end{array}$} \\
\cline { 2 - 9 } & Regression & PSM & Regression & PSM & Regression & PSM & Regression & PSM \\
\hline Coffee & -10.09 & -57.31 & $-400.24^{* * *}$ & $-686.91^{* * *}$ & $366.53^{*}$ & 358.82 & -49.76 & -69.05 \\
Yield & $(120.72)$ & $(127.12)$ & $(147.16)$ & $(200.06)$ & $(215.20)$ & $(309.39)$ & $(125.41)$ & $(171.00)$ \\
\hline Coffee & $1.00^{* * *}$ & $1.11^{*}$ & $-1.19^{* * *}$ & $-1.37^{* *}$ & $1.95^{* * *}$ & $3.12^{* * *}$ & $2.04^{* * *}$ & $3.04^{* * *}$ \\
Income & $(0.38)$ & $(0.61)$ & $(0.44)$ & $(0.64)$ & $(0.36)$ & $(0.78)$ & $(0.45)$ & $(0.65)$ \\
\hline Household & -0.16 & -0.17 & $-0.52^{*}$ & -0.08 & $0.58^{* * *}$ & 0.55 & $1.20^{* * *}$ & $1.74^{* * *}$ \\
\hline income & $(0.31)$ & $(0.37)$ & $(0.29)$ & $(0.49)$ & $(0.22)$ & $(0.41)$ & $(0.21)$ & $(0.55)$ \\
\hline \multirow{2}{*}{ Poverty } & 0.10 & 0.09 & 0.10 & 0.10 & $-0.27^{* * *}$ & $-0.27^{* * *}$ & $-0.30^{* * *}$ & $-0.25^{* * *}$ \\
& $(0.07)$ & $(0.08)$ & $(0.07)$ & $(0.08)$ & $(0.06)$ & $(0.12)$ & $(0.06)$ & $(0.08)$ \\
\hline
\end{tabular}

Robust standard errors are reported in parentheses. ${ }^{*} p<0.1{ }^{* *} p<0.05,{ }^{* * *} p<0.01$. Regression reports the results from ordinary least squares (OLS) regression models for the variables coffee yield, coffee income and household income; and from probit models for the variable poverty. The full regression results are reported in Table A1 in the Appendix A. PSM (propensity score matching) reports the results from propensity score matching using kernel-matching on a series of probit treatments. Source: Authors' estimation based on survey and interview data.
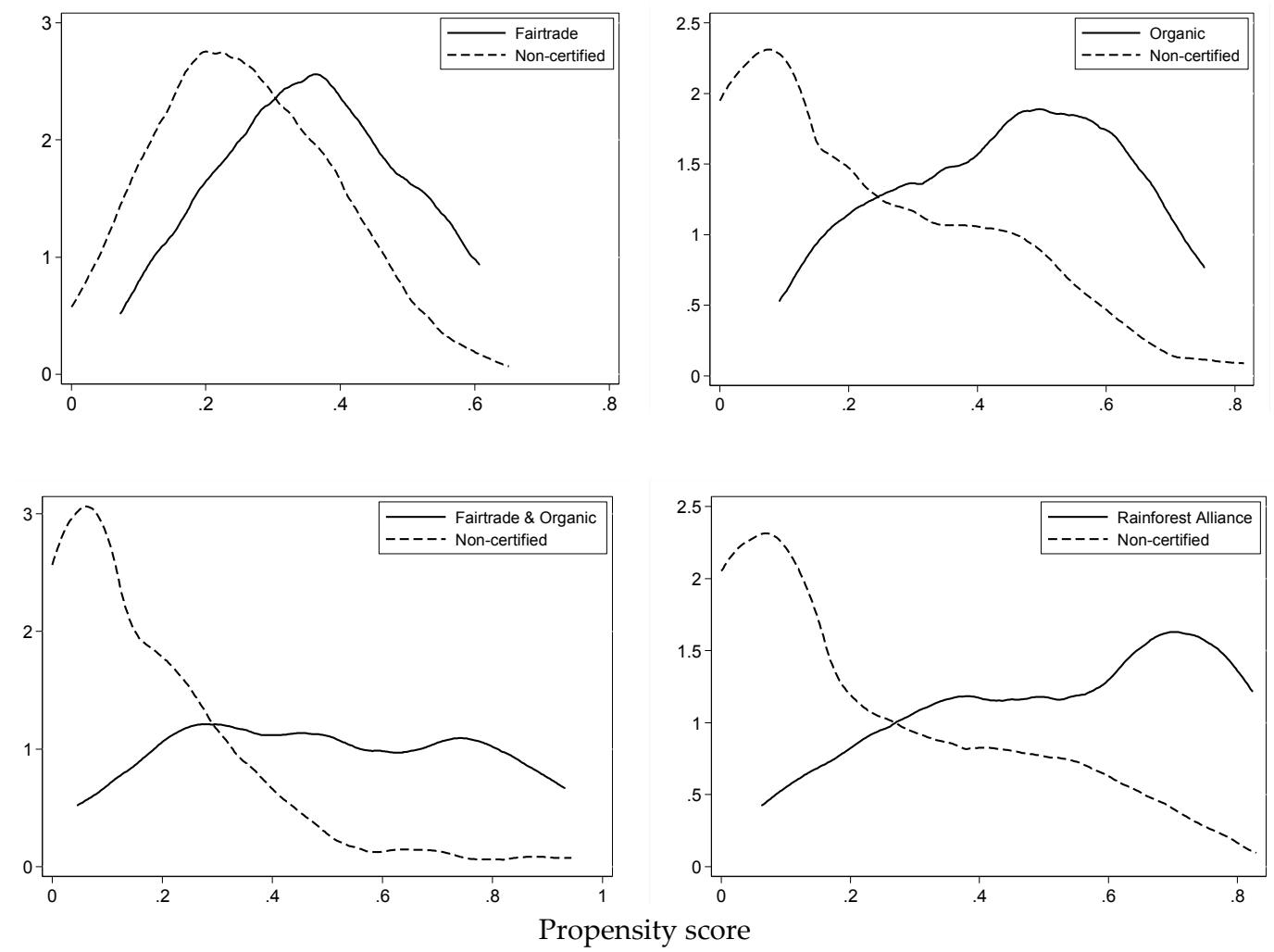

Figure 2. Propensity score distribution by certification scheme. Source: Authors' estimation.

Second, we find that membership in an Org-certified cooperative leads to significantly lower coffee yields, lower coffee income and lower total household income. We find no significant impact on the probability of being poor. Given that average coffee yields in the area are about $662 \mathrm{~kg} / \mathrm{ha}$, the estimated effect of a reduction in coffee yield of about 400 to $687 \mathrm{~kg} /$ ha is very large. While farm-gate 
coffee prices for Org-cooperative members are significantly higher than for members of non-certified cooperatives (Table 4), we find that coffee incomes are significantly lower. This implies that the negative yield effect associated with organic certification is not compensated by the higher farm-gate price. In this case, the lower coffee income does translate into an overall reduction in household income but has no implications towards poverty.

Third, membership in a cooperative with the double FT-Org certification has a positive impact on coffee yield (with the effect only being significant in the ordinary least squares (OLS) estimation and not in the PSM estimation), a significant positive impact on coffee income and on total household income, and a significant negative impact on poverty. The estimated effect on income is quite large, with participation in the double-certified cooperative leading to tripling coffee income and increasing total household income by $55 \%$. The effect on income is the result of a positive effect on coffee yields and a higher coffee price that reinforce each other. We find that participation in the double FT and Org-certified cooperative reduces poverty by 27 percentage points; given that the incidence of poverty in the research area is about $70 \%$, this is a large and important effect.

Fourth, we find that membership in a RA-certified cooperative has no effect on yield (estimates are less robust across the OLS and PSM method), but a positive effect on coffee income and total household income and a negative effect on poverty. Again, income and poverty effects are quite substantial: coffee income triples, total income increases by $174 \%$ and the likelihood to be poor reduces by 25 to 30 percentage points. Contrary to the FT-Org certification, these income and poverty effects of membership in a RA-certified cooperative mainly stem from a higher coffee price (Table 4). Compared with farmers in other certification schemes and non-certified farmers, RA-certified farmers receive a price that is 40 to $60 \%$ higher. This leads to very substantial income and welfare gains.

Other variables in the regression models have expected signs (Table A1). Coffee income increases with coffee area while coffee yield decreases with the coffee area but at a decreasing rate. The latter indicates that there is an inverse farm-size productivity relation, which is often found in the literature. Coffee yields and coffee income reduce with the age of the household head and with distance to the market. In addition, coffee income improves with the years of membership of the coffee cooperative. Land and livestock ownership increase income and reduce the probability of being poor. A larger family size and higher dependents in the household increase the probability of being poor. A large distance from the market reduces income and increases poverty.

\section{Discussion}

Our results show that there is substantial heterogeneity in the implications of private sustainability standards for smallholder coffee farmers in Ethiopia. Of the four certification schemes analyzed in this paper, two (RA and FT-Org) are found to have a quite substantial income-enhancing and poverty-reducing impact; one (FT) is found to only positively impact coffee income; and one (Org) is found to have an adverse effect. The result that RA certification does improve farmers' welfare while FT certification does not is a bit surprising. Given that FT focuses on producer welfare and empowerment while RA focuses more on environmental aspects than FT, we were expecting to find a larger welfare-improving effect from FT certification. Given the focus of Org certification on organic production methods and previous research showing this to be associated with lower yields, we were not expecting a substantial welfare-enhancing effect of Org certification. However, the adverse effect we find indicates that yield losses are not at all compensated by higher prices stemming from the price premium that consumers pay for organic-certified produce.

Our results are to some extent in line with previous findings in the literature. We find that FT and Org certification do not lead to higher household income and poverty reduction. Other studies have also indicated a lack of impact of FT and Org coffee certification on farm profits, farm income and poverty as for Nicaragua $[7,8,15]$ and Ethiopia $[18,42]$. In addition, we find that RA certification performs better than FT and Org in terms of impact on household income and poverty reduction. Ruben and Zuniga [21] come to similar conclusions for coffee farmers in Nicaragua. However, in 
their study, the superior impact of RA mainly comes from a large effect on yields, whereas we find that RA improves farmers' income especially through a large impact on producer prices though there is no significant difference in yields. Our results differ somewhat from the findings of Jena and Grote [20] who show a positive welfare effect of FT certification among coffee producers in India. Our results differ substantially from the findings of Chiputwa et al. [12] who show that FT certification reduces poverty among coffee farmers in Uganda, while Utz and Org certification have no impact. Differences in how the coffee supply chains are organized might contribute to explaining these different findings. In Uganda, FT-certified cooperatives supply milled coffee to private coffee exporters and farmers receive a price that is $30 \%$ higher for their coffee [12]. In Ethiopia, FT-certified cooperatives supply dried coffee cherries to the regional coffee union, where it is milled and processed, and receive a price that is $7 \%$ higher (Table 4). Moreover, in our study area, the FT cooperatives indicated never having received a cooperative FT bonus from the union because they failed to provide an investment plan, which is a requirement from the union to distribute the FT price premium further upstream the supply chain. The FT coffee chain is likely more developed in Uganda than in Ethiopia, where a lot of rent extraction takes place.

We put forward three major explanations for our findings. First, the observed positive effect on coffee income of RA, FT and FT-Org certification mainly come from a price effect, especially the superior effect of RA certification. The huge price difference between the RA and the other certification schemes are likely related to differences in the organization of the supply chain and differences in coffee quality. RA has an exclusive and short supply chain: RA-certified coffee is directly supplied to Oromia Forest and Wildlife Enterprise (OFWE) who directly exports the coffee. OFWE only exports RA-certified coffee as a specialty coffee. FT, Org and non-certified coffee is supplied by the cooperatives to the zonal coffee union that either exports the coffee as certified produce through direct contacts with buyers, or exports non-certified produce via the ECX. In this chain, it is more likely that certified and non-certified coffee gets mixed, that the volume of coffee sold on the international market as certified coffee is much lower than the volume supplied with a certificate, and that hence the price premium for certified coffee is spread out over a large number of farmers who supply certified coffee. The short and exclusive supply chain for RA coffee likely contributes to better producer prices through lower rent extraction throughout the chain. Moreover, RA farmers and cooperatives receive training from OFWE to establish an internal quality control system, leading not only to better prices on the international market but also to reduce coffee rejections. The ECX grading system, through which other coffee is supplied, results in a lot of coffee rejections due to poor quality [43]. In addition, the RA cooperative is paying a premium directly to farmers after the coffee is sold on the international market. This premium is proportional to the supplied volume, depends on international market prices and adds directly to farmers' income. Also, FT works with a premium but this is not directly paid out to farmers; rather, it is invested in the cooperative or in community development. This benefits farmers only indirectly. In our study area, the FT cooperatives indicated never having received a premium from the union because they failed to provide an investment plan, which is a requirement of the union to distribute the FT price premium further upstream the supply chain.

Second, differences in the coffee production systems can explain some results, particularly the observed differences in impact of coffee certification on yield. The positive effect of FT-Org certification on coffee yield might be related to a more intensive production system with more shrubs per hectare among FT-Org-certified farmers. This is supported by a positive non-declining relationship between shrub density and coffee yield (Table A1). Likewise, the lack of a yield effect for FT and RA certification might be related to the age of the coffee shrubs with shrubs being substantially younger among FT farmers and substantially older among RA farmers. This is confirmed by the positive but declining relationship between coffee age and coffee yield. In addition, the higher labor intensity of coffee production among FT farmers likely explains why a modest impact on coffee income does not result in an overall income effect. These and similar agronomic differences are very rarely taken into account in economic studies on the impact of certification while they might be important to understand observed effects. 
Third, cooperative level heterogeneity and location matters. For instance, it has been shown by [44-47] that heterogeneity among agricultural cooperatives in Rwanda and Ethiopia importantly determines the impact that cooperative membership has on farm performance and farm incomes. With our sample, it is impossible to completely disentangle the impact of certification from the impact of membership in a specific cooperative and differences in the location of farmers. Based on summary statistics (Table 2) the RA-, Org- and FT-Org-certified cooperatives were identified as better-performing cooperatives with more members, larger coffee supplies, more capital, its own washing station and higher dividend payments. The FT-certified cooperative is more similar to the non-certified cooperatives. With our data, we cannot completely rule out selection bias due to cooperative heterogeneity: if the best performing cooperatives self-select into certification schemes, estimates might be biased upwards. Especially the estimated impact of RA and FT-Org certification might suffer from such overestimation as these cooperatives are among the better-performing cooperatives. It remains unclear to what extent the estimated effect of RA and FT-Org certification on income and poverty arises from the impact of certification or from the impact of membership in a well-performing cooperative. Also, the estimated impact of Org certification might be overestimated and is likely confounded with the impact of membership in a better-performing cooperative. Yet, removing this potential bias would result in an even more negative income effect and could result in an adverse effect on poverty reduction. To better take into account cooperative heterogeneity, one would need a larger and more diverse sample of farmers.

\section{Conclusions and Implications}

In this paper, we analyze the effects of various private sustainability standards in the coffee sector in Ethiopia. Our results point to very heterogeneous effects across standards. We find that participation in a Rainforest Alliance (RA) and in a double Fairtrade/Organic (FT-Org) certification scheme results in substantially higher incomes and lower poverty. In the case of RA, this effect mainly stems from higher farm-gate prices, while in the case of the double certification, it results from both higher prices and higher yields. We find no effect on household income and poverty from participation in a FT scheme. The price received by FT-certified farmers is higher than the price received by non-certified farmers, but the premium is not enough to result in substantial household income effects. We find a negative effect of participation in an Org certification scheme on household income, which mainly comes from lower yields that are not offset by the higher prices Org-certified farmers receive.

The heterogeneity in income and poverty effects of certification is related to differences in the organization of the coffee supply chain in Ethiopia, to heterogeneity in coffee quality, and to heterogeneity in the performance of coffee cooperatives. The latter is an important issue that is often ignored in the literature on the impact of private sustainability standards. Studies on the impact of private sustainability standards are often based on samples including a mixture of farmers in export and domestic supply chains, a mixture of contract and non-contract farmers, or a mixture of cooperative and non-cooperative members. This makes it difficult to partial out the impact of standards as estimated effects are confounded effects assessing the joint impact of inclusion in export chains, contract-farming schemes or cooperatives, and the adoption of standards. By only focusing on cooperative members, we limit this potential confoundedness. However, cooperatives are heterogeneous and, while we discuss this heterogeneity and how it influences the estimated effects with our data and sampling strategy (focused on comparing different certification schemes), we are unable to partial out the impact of certification from the impact of membership in a specific cooperative. To better take into account cooperative heterogeneity, one would need large datasets including multiple cooperatives certified to the same standard and operating in the same socio-economic and agro-ecologic environment, which is difficult to achieve.

Our results imply that the way private standards influence the welfare of smallholder farmers strongly depends on the organization and well-functioning of the cooperatives in the system; and that cooperatives performing less well may be an important challenge for living up to the claims and promises standards make. Strengthening the operational capacity of cooperatives can contribute to 
their efficiency in the implementation of the standards, which in turn increases the benefits to their members, as promised by the standards. In general, one should be conscientious about hopes for positive effects of private sustainability standards, as these effects are study area-specific (e.g., due to the specific organization of the Ethiopian coffee export supply chain in our case) and crucially depend on the proper functioning of cooperatives.

Supplementary Materials: The data used for econometric analysis in STATA, cooperative level and coffee production and marketing data in excel, and the STATA software code are available online at www.mdpi.com/ 2071-1050/9/2/246/s1.

Acknowledgments: We acknowledge funding from the NUFFIC Niche program, StrongBow Project. We thank seminar and conference participants in Leuven, Brussels and Rome for critical and useful comments on earlier versions of the paper.

Author Contributions: Fikadu Mitiku and Miet Maertens conceived the idea and designed the research Fikadu Mitiku has implemented the data collection and conducted the descriptive and econometric analysis. Yann de Mey has given advice for and contributed to analyzing the data. Fikadu Mitiku, Yann de Mey, and Miet Maertens have contributed to writing and editing the manuscript. Jan Nyssen has supervised the StrongBow Project and has given advice in data collection and editing of the paper. All authors have checked and approved the final version of the paper.

Conflicts of Interest: The authors declare no conflict of interest

\section{Appendix A}

Table A1. Full regression results of the effect of coffee certification on coffee yield, coffee income, household income and poverty.

\begin{tabular}{|c|c|c|c|c|}
\hline & Coffee Yield & Coffee Income & Household Income & Poverty \\
\hline Fairtrade & $\begin{array}{c}-10.09 \\
(120.72)\end{array}$ & $\begin{array}{c}1.00^{* * *} \\
(0.38)\end{array}$ & $\begin{array}{l}-0.16 \\
(0.31)\end{array}$ & $\begin{array}{c}0.10 \\
(0.07)\end{array}$ \\
\hline Organic & $\begin{array}{c}-400.24^{* * *} \\
(147.16)\end{array}$ & $\begin{array}{c}-1.19^{* * *} \\
(0.44)\end{array}$ & $\begin{array}{c}-0.52 \text { * } \\
(0.29)\end{array}$ & $\begin{array}{c}0.10 \\
(0.07)\end{array}$ \\
\hline Fairtrade and Organic & $\begin{array}{l}366.53 * \\
(215.20)\end{array}$ & $\begin{array}{c}1.95^{* * *} \\
(0.36)\end{array}$ & $\begin{array}{c}0.58^{* * *} \\
(0.22)\end{array}$ & $\begin{array}{c}-0.27^{* * *} \\
(0.06)\end{array}$ \\
\hline Rainforest Alliance & $\begin{array}{c}-49.76 \\
(125.41)\end{array}$ & $\begin{array}{c}2.04^{* * *} \\
(0.45)\end{array}$ & $\begin{array}{c}1.20^{* * *} \\
(0.21)\end{array}$ & $\begin{array}{c}-0.30^{* * *} \\
(0.06)\end{array}$ \\
\hline Female-headed household & $\begin{array}{c}313.05 \\
(388.72)\end{array}$ & $\begin{array}{l}-0.80 \\
(0.50)\end{array}$ & $\begin{array}{c}0.08 \\
(0.39)\end{array}$ & $\begin{array}{c}0.09 \\
(0.08)\end{array}$ \\
\hline Age household head & $\begin{array}{c}-7.44^{* *} \\
(3.20)\end{array}$ & $\begin{array}{l}-0.01 \\
(0.01)\end{array}$ & $\begin{array}{c}-2.6 \times 10^{-5} \\
(0.005)\end{array}$ & $\begin{array}{c}0.002 \\
(0.002)\end{array}$ \\
\hline Education household head & $\begin{array}{c}-4.89 \\
(11.15)\end{array}$ & $\begin{array}{c}0.02 \\
(0.03)\end{array}$ & $\begin{array}{c}0.02 \\
(0.03)\end{array}$ & $\begin{array}{c}-0.001 \\
(0.01)\end{array}$ \\
\hline Adults in household & $\begin{array}{c}26.09 \\
(25.71)\end{array}$ & $\begin{array}{c}0.04 \\
(0.07)\end{array}$ & $\begin{array}{c}0.03 \\
(0.05)\end{array}$ & $\begin{array}{c}0.05 * * * \\
(0.02)\end{array}$ \\
\hline Dependents in household & $\begin{array}{l}-22.50 \\
(23.12)\end{array}$ & $\begin{array}{c}0.05 \\
(0.06)\end{array}$ & $\begin{array}{l}-0.05 \\
(0.04)\end{array}$ & $\begin{array}{c}0.04^{* * *} \\
(0.01)\end{array}$ \\
\hline Coffee tree density & $\begin{array}{c}0.04 \\
(0.07)\end{array}$ & $\begin{array}{c}0.00 \\
(0.001)\end{array}$ & & \\
\hline Coffee tree density (squared) & $\begin{array}{c}8.91 \times 10^{-7} \\
\left(5.56 \times 10^{-6}\right)\end{array}$ & $\begin{array}{c}-8.02 \times 10^{-10} \\
\left(8.59 \times 10^{-9}\right)\end{array}$ & & \\
\hline Coffee age & $\begin{array}{c}6.73 \\
(7.70)\end{array}$ & $\begin{array}{l}-0.01 \\
(0.03)\end{array}$ & & \\
\hline Coffee age (squared) & $\begin{array}{l}-0.12 \\
(0.09)\end{array}$ & $\begin{array}{c}0.0001 \\
(0.0003)\end{array}$ & & \\
\hline Coffee area & $\begin{array}{c}-172.74 \text { *** } \\
(51.64)\end{array}$ & $\begin{array}{c}0.72 * * * \\
(0.19)\end{array}$ & & \\
\hline
\end{tabular}


Table A1. Cont.

\begin{tabular}{|c|c|c|c|c|}
\hline & Coffee Yield & Coffee Income & Household Income & Poverty \\
\hline Coffee area (squared) & $\begin{array}{l}9.31^{* *} \\
(3.60)\end{array}$ & $\begin{array}{c}-0.03^{* * *} \\
(0.01)\end{array}$ & & \\
\hline Total area & & & $\begin{array}{c}0.28^{* * *} \\
(0.05)\end{array}$ & $\begin{array}{c}-0.07^{* * *} \\
(0.02)\end{array}$ \\
\hline Total area (squared) & & & $\begin{array}{c}-0.01^{* * *} \\
(0.001)\end{array}$ & $\begin{array}{c}0.002^{* * *} \\
(0.0004)\end{array}$ \\
\hline Livestock (TLU) & $\begin{array}{c}-0.54 \\
(12.98)\end{array}$ & $\begin{array}{c}0.03 \\
(0.05)\end{array}$ & $\begin{array}{c}0.10^{* * *} \\
(0.03)\end{array}$ & $\begin{array}{c}-0.02 * * * \\
(0.01)\end{array}$ \\
\hline Relatives & $\begin{array}{l}-0.35 \\
(0.57)\end{array}$ & $\begin{array}{l}-0.001 \\
(0.001)\end{array}$ & $\begin{array}{l}0.0004 \\
(0.001)\end{array}$ & $\begin{array}{c}0.0002 \\
(0.0002)\end{array}$ \\
\hline Years coop member & $\begin{array}{l}10.84 \\
(8.57)\end{array}$ & $\begin{array}{c}0.07^{* * *} \\
(0.02)\end{array}$ & $\begin{array}{l}-0.02 \\
(0.02)\end{array}$ & $\begin{array}{c}0.002 \\
(0.004)\end{array}$ \\
\hline Distance to district town & $\begin{array}{c}-2.43^{* * *} \\
(0.47)\end{array}$ & $\begin{array}{c}-0.01^{* * *} \\
(0.002)\end{array}$ & $\begin{array}{c}-0.01^{* * *} \\
(0.002)\end{array}$ & $\begin{array}{c}0.003^{* * *} \\
(0.001)\end{array}$ \\
\hline Constant & $\begin{array}{c}1049.99 * * * \\
(239.83)\end{array}$ & $\begin{array}{c}6.44^{* * *} \\
(0.74)\end{array}$ & $\begin{array}{c}7.87^{* * *} \\
(0.43)\end{array}$ & \\
\hline Number of observations & $\begin{array}{c}425 \\
529 * * *\end{array}$ & $\begin{array}{c}425 \\
1370 * * *\end{array}$ & $\begin{array}{c}425 \\
1183 * * *\end{array}$ & 425 \\
\hline $\begin{array}{c}\text { (Pseudo) } R^{2} \\
\text { Wald Chi }{ }^{2} \\
\text { Log Likelihood }\end{array}$ & 0.12 & 0.33 & 0.28 & $\begin{array}{c}0.38 \\
103.31^{* * *} \\
-172.07\end{array}$ \\
\hline
\end{tabular}

Robust standard errors in parentheses, ${ }^{*} p<0.1,{ }^{* *} p<0.05,{ }^{* * *} p<0.01$. For poverty, marginal effects at sample means (MEMs) are reported. Source: Authors' estimation based on survey and interview data.

Table A2. Full probit model results explaining the probability of participating in a certification scheme (i.e., first stage result of the propensity score estimation).

\begin{tabular}{|c|c|c|c|c|}
\hline Variables & FT & Org & FT-Org & RA \\
\hline Female household head & $\begin{array}{c}0.150 \\
(0.410)\end{array}$ & $\begin{array}{c}0.420 \\
(0.440)\end{array}$ & $\begin{array}{l}0.968^{* *} \\
(0.391)\end{array}$ & $\begin{array}{l}-0.032 \\
(0.460)\end{array}$ \\
\hline Age household head & $\begin{array}{l}0.001 \\
(0.03)\end{array}$ & $\begin{array}{l}-0.064 \\
(0.036)\end{array}$ & $\begin{array}{c}0.036 \\
(0.038)\end{array}$ & $\begin{array}{l}-0.019 \\
(0.033)\end{array}$ \\
\hline Age household head ${ }^{2}$ & $\begin{array}{l}-2.6 \times 10^{-5} \\
\left(2.7 \times 10^{-4}\right)\end{array}$ & $\begin{array}{l}0.0005 * \\
(0.0003)\end{array}$ & $\begin{array}{l}-0.0003 \\
(0.0004)\end{array}$ & $\begin{array}{c}-0.00007 \\
(0.0003)\end{array}$ \\
\hline Education household head & $\begin{array}{l}-0.036 \\
(0.027)\end{array}$ & $\begin{array}{l}-0.034 \\
(0.030)\end{array}$ & $\begin{array}{c}0.034 \\
(0.031)\end{array}$ & $\begin{array}{l}-0.018 \\
(0.031)\end{array}$ \\
\hline Adults in household & $\begin{array}{l}-0.069 \\
(0.066)\end{array}$ & $\begin{array}{l}-0.109 \\
(0.072)\end{array}$ & $\begin{array}{l}-0.056 \\
(0.075)\end{array}$ & $\begin{array}{l}-0.066 \\
(0.068)\end{array}$ \\
\hline Dependents in household & $\begin{array}{l}-0.024 \\
(0.049) \\
\end{array}$ & $\begin{array}{c}0.001 \\
(0.054) \\
\end{array}$ & $\begin{array}{l}-0.097 \\
(0.059)\end{array}$ & $\begin{array}{c}0.012 \\
(0.051)\end{array}$ \\
\hline Total area & $\begin{array}{c}0.049 \\
(0.040)\end{array}$ & $\begin{array}{c}0.094^{* *} \\
(0.039)\end{array}$ & $\begin{array}{c}0.110^{* *} \\
(0.044)\end{array}$ & $\begin{array}{l}-0.249 \\
(0.007)\end{array}$ \\
\hline Livestock (TLU) & $\begin{array}{c}-0.11^{* * *} \\
(0.038)\end{array}$ & $\begin{array}{c}-0.139 * * * \\
(0.047)\end{array}$ & $\begin{array}{c}-0.206^{* * *} \\
(0.053)\end{array}$ & $\begin{array}{c}-0.249^{* * *} \\
(0.042)\end{array}$ \\
\hline Relatives & $\begin{array}{l}-0.006 \\
(0.004) \\
\end{array}$ & $\begin{array}{l}0.007 * * \\
(0.003)\end{array}$ & $\begin{array}{c}0.014^{* * *} \\
(0.003)\end{array}$ & $\begin{array}{c}0.007 * * \\
(0.003)\end{array}$ \\
\hline Distance to district town & $\begin{array}{l}-0.002 \\
(0.001)\end{array}$ & $\begin{array}{c}-0.009^{* * *} \\
(0.003)\end{array}$ & $\begin{array}{l}-0.003 \\
(0.002)\end{array}$ & $\begin{array}{c}-0.007^{* * *} \\
(0.002)\end{array}$ \\
\hline Constant & $\begin{array}{c}0.631 \\
(0.823)\end{array}$ & $\begin{array}{l}2.519 * * \\
(0.956)\end{array}$ & $\begin{array}{l}-1.076 \\
(1.079)\end{array}$ & $\begin{array}{l}1.933 * * \\
(0.883)\end{array}$ \\
\hline Number of observations & 217 & 218 & 219 & 236 \\
\hline Wald Chi ${ }^{2}$ & $23.04^{* *}$ & $64.43^{* * *}$ & $100.94^{* * *}$ & $100.04^{* * *}$ \\
\hline Pseudo $R^{2}$ & 0.09 & 0.24 & 0.38 & 0.33 \\
\hline Log Likelihood & -118.31 & -98.86 & -81.84 & -101.76 \\
\hline
\end{tabular}

Standard errors in parentheses, ${ }^{*} p<0.1,{ }^{* *} p<0.05,{ }^{* * *} p<0.01$. Source: Authors' estimation based on survey and interview data. 
Table A3. Balancing properties in the matched sample.

\begin{tabular}{|c|c|c|c|c|c|c|c|c|c|c|c|c|}
\hline Variables & Non-Certified & FT & $t$-Test & Non-Certified & Org & $t$-Test & Non-Certified & FT-Org & $t$-Test & Non-Certified & RA & $t$-Test \\
\hline Female household head & 0.06 & 0.06 & $\begin{array}{c}0.21 \\
(0.83) \\
\end{array}$ & 0.11 & 0.07 & $\begin{array}{l}-0.84 \\
(0.40) \\
\end{array}$ & 0.23 & 0.15 & $\begin{array}{l}-0.92 \\
(0.36) \\
\end{array}$ & 0.04 & 0.04 & $\begin{array}{c}0.67 \\
(0.50) \\
\end{array}$ \\
\hline Age household head & 48.88 & 47.28 & $\begin{array}{l}-0.59 \\
(0.56)\end{array}$ & 43.58 & 45.12 & $\begin{array}{c}0.54 \\
(0.59)\end{array}$ & 47.94 & 49.04 & $\begin{array}{c}0.40 \\
(0.69)\end{array}$ & 44.03 & 43.11 & $\begin{array}{c}-0.42 \\
(0.68)\end{array}$ \\
\hline Age household head ${ }^{2}$ & 2538.7 & 2442.9 & $\begin{array}{l}-0.48 \\
(0.63)\end{array}$ & 2130.7 & 2280.7 & $\begin{array}{c}0.49 \\
(0.62)\end{array}$ & 2449 & 2620.7 & $\begin{array}{c}0.57 \\
(0.57)\end{array}$ & 2077.4 & 1980.5 & $\begin{array}{c}-0.44 \\
(0.66)\end{array}$ \\
\hline Education household head & 2.82 & 2.87 & $\begin{array}{l}-0.08 \\
(0.94)\end{array}$ & 3.25 & 2.97 & $\begin{array}{l}-0.46 \\
(0.64)\end{array}$ & 4.45 & 4.63 & $\begin{array}{c}0.24 \\
(0.81)\end{array}$ & 2.55 & 3.56 & $\begin{array}{l}1.76^{*} \\
(0.08)\end{array}$ \\
\hline Adults in household & 3.42 & 3.32 & $\begin{array}{l}-0.36 \\
(0.72)\end{array}$ & 3.21 & 3.18 & $\begin{array}{l}-0.12 \\
(0.90)\end{array}$ & 3.82 & 3.38 & $\begin{array}{l}-1.38 \\
(0.17)\end{array}$ & 3.27 & 3.35 & $\begin{array}{c}0.32 \\
(0.75)\end{array}$ \\
\hline Dependents in household & 3.39 & 3.51 & $\begin{array}{c}0.34 \\
(0.73) \\
\end{array}$ & 3.48 & 3.35 & $\begin{array}{l}-0.39 \\
(0.70) \\
\end{array}$ & 2.68 & 2.83 & $\begin{array}{c}0.40 \\
(0.94) \\
\end{array}$ & 3.37 & 3.52 & $\begin{array}{c}0.41 \\
(0.68) \\
\end{array}$ \\
\hline Total area & 2.78 & 2.76 & $\begin{array}{c}0.06 \\
(0.96) \\
\end{array}$ & 2.97 & 2.96 & $\begin{array}{l}-0.01 \\
(0.99) \\
\end{array}$ & 2.54 & 2.99 & $\begin{array}{c}0.73 \\
(0.47) \\
\end{array}$ & 2.50 & 2.10 & $\begin{array}{l}-0.07 \\
(0.29) \\
\end{array}$ \\
\hline Livestock (TLU) & 4.44 & 4.37 & $\begin{array}{l}-0.12 \\
(0.90) \\
\end{array}$ & 4.78 & 4.39 & $\begin{array}{l}-0.64 \\
(0.52) \\
\end{array}$ & 4.10 & 4.03 & $\begin{array}{l}-0.14 \\
(0.89) \\
\end{array}$ & 3.73 & 3.07 & $\begin{array}{l}-1.43 \\
(0.15) \\
\end{array}$ \\
\hline Relatives & 25.64 & 23.94 & $\begin{array}{l}-0.43 \\
(0.67)\end{array}$ & 35.11 & 42.75 & $\begin{array}{c}1.21 \\
(0.22)\end{array}$ & 62.33 & 64.67 & $\begin{array}{c}0.24 \\
(0.81)\end{array}$ & 49.23 & 35.68 & $\begin{array}{l}-1.57 \\
(0.12) \\
\end{array}$ \\
\hline Distance to district town & 76.29 & 81.52 & $\begin{array}{c}0.39 \\
(0.70)\end{array}$ & 33.09 & 39.75 & $\begin{array}{l}1.74^{*} \\
(0.08)\end{array}$ & 46.33 & 57.50 & $\begin{array}{c}1.44 \\
(0.15)\end{array}$ & 42.11 & 46.13 & $\begin{array}{c}0.68 \\
(0.50)\end{array}$ \\
\hline Number of observations & 155 & 62 & & 155 & 63 & & 155 & 64 & & 155 & 81 & \\
\hline Pseudo $R^{2}$ matched sample & & 0.006 & & & 0.036 & & & 0.042 & & & 0.034 & \\
\hline$p$ value LR test & & 1.000 & & & 0.810 & & & 0.813 & & & 0.789 & \\
\hline Mean Bias & & 5.3 & & & 9.5 & & & 11.4 & & & 13.6 & \\
\hline Median Bias & & 6.0 & & & 9.2 & & & 9.7 & & & 9.1 & \\
\hline
\end{tabular}

Comparisons are made between matched samples of certified and non-certified households for the four categories of certificates using $t$-tests. The figures in parentheses are p-values for the $t$-test. ${ }^{*} p<0.1$. Source: Authors' estimation based on survey and interview data. 
Table A4. Simulation-based sensitivity analysis of propensity score-matching estimates to violation of the conditional independence assumption.

\begin{tabular}{|c|c|c|c|c|c|c|c|c|c|c|c|c|}
\hline \multirow[b]{2}{*}{ Variables } & \multicolumn{3}{|c|}{ FT } & \multicolumn{3}{|c|}{ Org } & \multicolumn{3}{|c|}{ F-Org } & \multicolumn{3}{|c|}{ RA } \\
\hline & $\begin{array}{c}\text { Estimate } \\
\text { Effect }^{\text {a }}\end{array}$ & $\begin{array}{l}\text { Outcome } \\
\text { Effect } b\end{array}$ & $\begin{array}{c}\text { Selection } \\
\text { Effect }^{c}\end{array}$ & $\begin{array}{c}\text { Estimate } \\
\text { Effect }\end{array}$ & $\begin{array}{c}\text { Outcome } \\
\text { Effect }\end{array}$ & $\begin{array}{c}\text { Selection } \\
\text { Effect }\end{array}$ & $\begin{array}{c}\text { Estimate } \\
\text { Effect }\end{array}$ & $\begin{array}{c}\text { Outcome } \\
\text { Effect }\end{array}$ & $\begin{array}{c}\text { Selection } \\
\text { Effect }\end{array}$ & $\begin{array}{c}\text { Estimate } \\
\text { Effect }\end{array}$ & $\begin{array}{c}\text { Outcome } \\
\text { Effect }\end{array}$ & $\begin{array}{c}\text { Selection } \\
\text { Effect }\end{array}$ \\
\hline Poverty & $0.89 \%$ & 1.11 & 0.99 & $-0.88 \%$ & 0.01 & 1.09 & $-3.2 \%$ & 1.12 & 1.13 & $-1.8 \%$ & 1.19 & 1.09 \\
\hline Income & $15.3 \%$ & 0.99 & 1.08 & $7.5 \%$ & 1.06 & 1.07 & $0.8 \%$ & 1.12 & 0.99 & $2.0 \%$ & 1.13 & 1.11 \\
\hline Coffee Income & $3.5 \%$ & 1.09 & 1.02 & $2.0 \%$ & 1.06 & 1.25 & $0.6 \%$ & 1.12 & 1.16 & $2.8 \%$ & 1.19 & 1.10 \\
\hline Coffee Yield & $-2.8 \%$ & 1.04 & 1.08 & $1.3 \%$ & 1.17 & 1.15 & $-2.1 \%$ & 1.04 & 1.13 & $-50.53 \%$ & 1.04 & 1.14 \\
\hline
\end{tabular}

a The estimator effect indicates the extent of change in the treatment effect under the presence of a binary confounder compared to the baseline estimate. $\mathrm{b}$ The outcome effect measures the effect of the binary confounder on the untreated outcome; ${ }^{\mathrm{c}}$ The selection effect measures the effect of the binary confounder on the relative probability of selection into treatment. Source: Authors' estimation based on survey and interview data 


\section{References}

1. Beghin, J.C.; Maertens, M.; Swinnen, J. Nontariff Measures and Standards in Trade and Global Value Chains. Annu. Rev. Resour. Econ. 2015, 7, 425-450. [CrossRef]

2. Henson, S.; Humphrey, J. Understanding the Complexities of Private Standards in Global Agri-Food Chains as They Impact Developing Countries. J. Dev. Stud. 2010, 46, 1628-1646. [CrossRef] [PubMed]

3. Schuster, M.; Maertens, M. The Impact of Private Food Standards on Developing Countries' Export Performance: An Analysis of Asparagus Firms in Peru. World Dev. 2015, 66, 208-221. [CrossRef]

4. Fairtrade International. Fairtrade International, Benefits of Fairtrade. Available online: http://www. fairtrade.net/about-fairtrade/benefits-of-fairtrade.html (accessed on 4 January 2016).

5. Rainforest Alliance. Rainforest Alliance, Certification, Verification and Validation Services. Available online: http:/ / www.rainforest-alliance.org/certification-verification (accessed on 4 January 2016).

6. Weber, J.G. How much more do growers receive for Fair Trade-organic coffee? Food Policy 2011, 36, 678-685. [CrossRef]

7. Valkila, J.; Nygren, A. Impacts of Fair Trade certification on coffee farmers, cooperatives, and laborers in Nicaragua. Agric. Hum. Values 2010, 27, 321-333. [CrossRef]

8. Valkila, J. Fair Trade organic coffee production in Nicaragua-Sustainable development or a poverty trap? Ecol. Econ. 2009, 68, 3018-3025. [CrossRef]

9. Wollni, M.; Zeller, M. Do farmers benefit from participating in specialty markets and cooperatives? The case of coffee marketing in Costa Rica1. Agric. Econ. 2007, 37, 243-248. [CrossRef]

10. Bacon, C. Confronting the Coffee Crisis: Can Fair Trade, Organic, and Specialty Coffees Reduce Small-Scale Farmer Vulnerability in Northern Nicaragua? World Dev. 2005, 33, 497-511. [CrossRef]

11. Bacon, C.M.; Ernesto Méndez, V.; Gómez, M.E.F.; Stuart, D.; Flores, S.R.D. Are Sustainable Coffee Certifications Enough to Secure Farmer Livelihoods? The Millenium Development Goals and Nicaragua's Fair Trade Cooperatives. Globalizations 2008, 5, 259-274. [CrossRef]

12. Chiputwa, B.; Spielman, D.J.; Qaim, M. Food Standards, Certification, and Poverty among Coffee Farmers in Uganda. World Dev. 2015, 66, 400-412. [CrossRef]

13. Chiputwa, B.; Qaim, M. Sustainability Standards, Gender, and Nutrition among Smallholder Farmers in Uganda. J. Dev. Stud. 2016, 52, 1241-1257. [CrossRef]

14. Beuchelt, T.D.; Zeller, M. The role of cooperative business models for the success of smallholder coffee certification in Nicaragua: A comparison of conventional, organic and Organic-Fairtrade certified cooperatives. Renew. Agric. Food Syst. 2013, 28, 195-211. [CrossRef]

15. Beuchelt, T.D.; Zeller, M. Profits and poverty: Certification's troubled link for Nicaragua's organic and fairtrade coffee producers. Ecol. Econ. 2011, 70, 1316-1324. [CrossRef]

16. Barham, B.L.; Callenes, M.; Gitter, S.; Lewis, J.; Weber, J. Fair Trade/Organic Coffee, Rural Livelihoods, and the "Agrarian Question": Southern Mexican Coffee Families in Transition. World Dev. 2011, 39, 134-145. [CrossRef]

17. Barham, B.L.; Weber, J.G. The Economic Sustainability of Certified Coffee: Recent Evidence from Mexico and Peru. World Dev. 2012, 40, 1269-1279. [CrossRef]

18. Jena, P.R.; Chichaibelu, B.B.; Stellmacher, T.; Grote, U. The impact of coffee certification on small-scale producers' livelihoods: A case study from the Jimma Zone, Ethiopia. Agric. Econ. 2012, 43, 429-440. [CrossRef]

19. Mendez, V.E.; Bacon, C.M.; Olson, M.; Petchers, S.; Herrador, D.; Carranza, C.; Trujillo, L.; Guadarrama-Zugasti, C.; Cordon, A.; Mendoza, A. Effects of Fair Trade and organic certifications on small-scale coffee farmer households in Central America and Mexico. Renew. Agric. Food Syst. 2010, 25, 236-251. [CrossRef]

20. Jena, P.R.; Grote, U. Fairtrade Certification and Livelihood Impacts on Small-scale Coffee Producers in a Tribal Community of India. Appl. Econ. Perspect. Policy 2016. [CrossRef]

21. Ruben, R.; Zuniga, G. How standards compete: Comparative impact of coffee certification schemes in Northern Nicaragua. Supply Chain Manag. 2011, 16, 98-109. [CrossRef]

22. Van Rijsbergen, B.; Elbers, W.; Ruben, R.; Njuguna, S.N. The Ambivalent Impact of Coffee Certification on Farmers' Welfare: A Matched Panel Approach for Cooperatives in Central Kenya. World Dev. 2016, 77, 277-292. [CrossRef]

23. Ruben, R.; Fort, R. The Impact of Fair Trade Certification for Coffee Farmers in Peru. World Dev. 2012, 40, 570-582. [CrossRef] 
24. Johannessen, S.; Wilhite, H. Who Really Benefits from Fairtrade? An Analysis of Value Distribution in Fairtrade Coffee. Globalizations 2010, 7, 525-544. [CrossRef]

25. Marx, A.; Maertens, M.; Swinnen, J.; Wouters, J. Private Standards and Global Governance: Legal and Economic Perspectives; Edward Elgar Publishing: Cheltenham, UK, 2012.

26. Minten, B.; Tamiru, S.; Kuma, T.; Nyarko, Y. Structure and Performance of Ethiopia's Coffee Export Sector. In Working Paper 66; International Food Policy Research Institute (IFPRI): Addis Ababa, Ethiopia, 2014.

27. International Coffee Organization. Available online: http://www.ico.org/new_historical.asp (accessed on 20 December 2014).

28. Tefera, A.; Tefera, T. Ethiopia: Coffee Annual, Coffee Annual Report; ET 1402; USDA Foreign Agriculture Service: Addis Ababa, Ethiopia, 2014.

29. Francom, M.G.; Tefera, A. Ethiopia: Coffee Annual, Coffee Production and Exports Remain Steady; ET1615; USAD Foreign Agriculture Service: Addis Ababa, Ethiopia, 2016.

30. Minten, B.; Dereje, M.; Engida, E.; Tamiru, S. Who Benefits from the Rapidly Increasing Voluntary Sustainability Standards? Evidence from Fairtrade and Organic Certified Coffee in Ethiopia; Working Paper 71; International Food Policy Research Institute (IFPRI): Addis Ababa, Ethiopia, 2015.

31. Wiersum, K.F.; Gole, T.W.; Gatzweiler, F.; Volkmann, J.; Bognetteau, E.; Wirtu, O. Certification of Wild Coffee in Ethiopia: Experiences and Challenges. For. Trees Livelihoods 2008, 18, 9-21. [CrossRef]

32. Stillmacher, T.; Grote, U. Forest Coffee Certification in Ethiopia: Economic Boon or Ecological Bane? ZEF Working Paper Series 76; University of Bonn: Bonn, Germany, 2011.

33. Ministry of Finance and Economic Development. Ethiopia's Progress towards Eradicating Poverty: An Interim Report on Poverty Analysis Study; Ministry of Finance and Economic Development: Addis Ababa, Ethiopia, 2012.

34. Sen, A. Ingredients of Famine Analysis: Availability and Entitlements. Q. J. Econ. 1981, 96, 433-464. [CrossRef] [PubMed]

35. Bebbington, A. Capitals and Capabilities: A Framework for Analyzing Peasant Viability, Rural Livelihoods and Poverty. World Dev. 1999, 27, 2021-2044. [CrossRef]

36. Rosenbaum, P.R.; Rubin, D.B. The central role of the propensity score in observational studies for causal effects. Biometrika 1983, 70, 41-55. [CrossRef]

37. Caliendo, M.; Kopeinig, S. Some Practical Guidance for the implementation of Propensity Score Matching. J. Econ. Surv. 2008, 22, 31-72. [CrossRef]

38. Lechner, M. Program Heterogeneity and Propensity Score Matching: An Application to the Evaluation of Active Labor Market Policies. Rev. Econ. Stat. 2002, 84, 205-220. [CrossRef]

39. Imbens, G.W. Nonparametric estimation of average treatment effects under exogeneity: A review. Rev. Econ. Stat. 2004, 86, 4-29. [CrossRef]

40. Lampach, N.; Morawetz, U.B. Credibility of propensity score matching estimates. An example from Fair Trade certification of coffee producers. Appl. Econ. 2016, 48, 4227-4237. [CrossRef]

41. Ichino, A.; Mealli, F.; Nannicini, T. From temporary help jobs to permanent employment: What can we learn from matching estimators and their sensitivity? J. Appl. Econom. 2008, 23, 305-327. [CrossRef]

42. Cramer, C.; Johnston, D.; Mueller, B.; Oya, C.; Sender, J. Fairtrade and Labour Markets in Ethiopia and Uganda. J. Dev. Stud. 2016. [CrossRef]

43. Fikade, B. Trouble brewing for coffee exports. The Reporter, 1 February 2014.

44. Verhofstadt, E.; Maertens, M. Smallholder cooperatives and agricultural performance in Rwanda: Do organizational differences matter? Agric. Econ. 2014, 45, 39-52. [CrossRef]

45. Verhofstadt, E.; Maertens, M. Can Agricultural Cooperatives Reduce Poverty? Heterogeneous Impact of Cooperative Membership on Farmers' Welfare in Rwanda. Appl. Econ. Perspect. Policy 2014. [CrossRef]

46. Ruben, R.; Heras, J. Social Capital, Governance and Performance of Ethiopia Coffee Cooperatives. Ann. Public Coop. Econ. 2012, 83, 463-484. [CrossRef]

47. Woubie, A.A. Coffee Marketing Cooperatives and rural Poverty Alleviation: Evidence from Southern Ethiopia. Ph.D. Thesis, Radboud University Nijmegen, Radboud Repository, Nijmegen, The Netherlands, 16 October 2015.

(C) 2017 by the authors; licensee MDPI, Basel, Switzerland. This article is an open access article distributed under the terms and conditions of the Creative Commons Attribution (CC BY) license (http:/ / creativecommons.org/licenses/by/4.0/). 